\title{
Development and characterisation of polymorphic microsatellite markers in the pearl oyster Pteria penguin (Roding, 1798)
}

\author{
NAN ZHANG, ZHENHUA MA, DIANCHANG ZHANG, HUAYANG GUO, \\ LIN LIN*AND SHIGUI JIANG \\ Division of Aquaculture and Biotechnology, South China Sea Fisheries Research Institute, Chinese Academy \\ of Fishery Sciences, Guangzhou - 510 300, China \\ *Key Laboratory of South China Sea Fishery Resources Exploitation and Utilization, Ministry of Agriculture, \\ Guangzhou - 510 300, China \\ e-mail: zhenhua.ma@hotmail.com
}

\begin{abstract}
We developed and characterised 12 polymorphic microsatellite loci for Pteria penguin (Roding, 1798), an important pearl oyster species for pearl production in China. The number of observed alleles per locus ranged from 5 to 26 within 46 individuals. The observed and expected heterozygosities per locus ranged from 0.2 to 0.925 and 0.707 to 0.945 , respectively. The polymorphism information content values per locus ranged from 0.656 to 0.929 . Ten loci were in accordance with Hardy-Weinberg equilibrium and no significant linkage disequilibrium was detected between loci. These new microsatellite markers will be useful for population and conservation genetic studies of $P$. penguin.
\end{abstract}

Keywords: Conservation, Genetics, Microsatellite locus, Pearl oyster, Pteria penguin

The pearl oyster Pteria penguin (Roding, 1798) (Family: Pteriidae), is mainly distributed along the coastal areas of South China, south of Kyushu and Ryukyu Islands in Japan and Philippines. P. penguin is extensively cultured in South China and has been used to produce large round pearls and blister pearls (Mao et al., 2003). Currently, the germplasm of $P$. penguin has degenerated significantly due to overfishing and environmental pollution. Reduced growth in hatchery produced seeds leading to decrease in yield of the pearl oyster, has been haunting this aquaculture industry. Therefore, reasonable stock management as well as genetic improvement programmes are required for the sustainable development of the pearl oyster aquaculture industry. Microsatellite markers have been considered as useful tools to identify population genetic variation due to their codominance, abundance and unambiguous scoring of alleles (Tautz, 1989). In this study, we attempted to develop and characterise polymorphic microsatellite markers aimed at conservation of genetic diversity of P. penguin.

P. penguin (46 nos.) were collected from Beihai, Guangxi Province, China were dissected and the adductor muscles were immediately preserved in $95 \%$ ethyl alcohol $(\mathrm{EtOH})$ and stored in $-20^{\circ} \mathrm{C}$ freezer until DNA extraction. Total genomic DNA was extracted using the CTAB (cetyl trimethylammonium bromide) method (Doyle, 1987). A dinucleotide-enriched genomic library was constructed following the method described by Ma and Chen (2009). The sample DNA was digested by $M$ seI restriction enzyme (New England Biolabs, USA). The DNA fragments were ligated to adapters, OligoA (5'-TACTCAGGACTCAT-3') andOligoB(5'-GACGATGAGTCCTGAG-3'). Theligated products were pre-amplified in a $25-\mu 1$ reaction system using a specific primer (5'-GAT GAG TCC TGA GTA A-3') to validate successful ligation and to increase DNA concentration. The DNA fragments were eluted from the magnetic beads and then further amplified by the adapter specific primer. The final amplification products were ligated into the pMD18-T vectors (Takara, Japan) and transformed into Escherichia coli DH5 $\alpha$. The positive clones were randomly sequenced on ABI 3730xl DNA analysers at Life Technologies (Guangzhou, China). A total of 198 positive clones were sequenced and 125 microsatellite repeats were obtained. Subsequently, 53 microsatellite loci were selected to design primer pairs by PRIMER PREMIER 5 software (Premier Biosoft International, USA).

The designed primers were used to evaluate the polymorphisms of each locus within 12 individuals of $P$. penguin. Polymerase chain reaction (PCR) was done in a reaction volume of $15 \mu \mathrm{l}$, comprising $1 \times$ buffer, $0.2 \mathrm{~mm}$ dNTP, $0.2 \mu \mathrm{m}$ primer pairs, $1.5 \mathrm{~mm} \mathrm{MgCl}_{2}$, $1 \mathrm{U}$ Taq polymerase (Takara, Japan) and about $50 \mathrm{ng}$ genomic DNA. The PCR amplifications were carried 
out under the following conditions: initial denaturatiuon at $94^{\circ} \mathrm{C}$ for $5 \mathrm{~min}$, followed by 35 cycles of denaturation at $94^{\circ} \mathrm{C}$ for $45 \mathrm{sec}$, annealing at the optimised annealing temperature (Table 1) for $30 \mathrm{sec}$, extension at $72^{\circ} \mathrm{C}$ for $30 \mathrm{sec}$ and a final extension at $72^{\circ} \mathrm{C}$ for $10 \mathrm{~min}$. The PCR products were separated on $8 \%$ denaturing polyacrylamide gel and visualised by silver staining. We assessed the
0.741 and 0.856 , respectively. The PIC values ranged from 0.656 to 0.929 . Results of the study indicates that the genetic diversity of $P$. penguin in the wild population is high and this result is consistent with the findings obtained by using AFLP analysis (Peng et al., 2012). Loci Ptpe_134 and Ptpe_128 significantly deviated

Table 1. Characteristics of the 12 selected microsatellite loci in P. Penguin

\begin{tabular}{|c|c|c|c|c|c|c|c|c|c|c|}
\hline Locus & Repeat motif & $\mathrm{Ta}\left({ }^{\circ} \mathrm{C}\right)$ & Primer sequence (5'-3') & Size range (bp) & $N_{a}$ & $H_{O}$ & $H_{E}$ & $P$ & $P I C$ & Accession No. \\
\hline Ptpe_134 & $(\mathrm{CA})_{34}$ & 58 & $\begin{array}{l}\text { F: CAGACTTTGGTTACATTTGCG } \\
\text { R: GGTCGTCTTGAGGTTTCGTT }\end{array}$ & 184-192 & 5 & 0.2 & 0.707 & $<0.001$ & 0.656 & KJ606766 \\
\hline Ptpe_137 & $(\mathrm{TG})_{7} \mathrm{TA}(\mathrm{TG})_{10}$ & 60 & $\begin{array}{l}\text { F: CCATTCTTTACTTCAGAGGCAA } \\
\text { R: CATTTACGCAAATTTCCACG }\end{array}$ & $278-294$ & 8 & 0.738 & 0.796 & 0.611 & 0.756 & KJ606767 \\
\hline Ptpe_425 & $(\mathrm{TG})_{5} \mathrm{TA}(\mathrm{TG})_{24}$ & 60 & $\begin{array}{l}\text { F: GCTACCACAACATGACAACAGA } \\
\text { R: TGCGTCAGACAGGTAACTTTG }\end{array}$ & $245-271$ & 12 & 0.867 & 0.918 & 0.437 & 0.900 & KJ606768 \\
\hline Ptpe_429 & $(\mathrm{GT})_{11} \mathrm{~A}(\mathrm{TG})_{23}$ & 60 & $\begin{array}{l}\text { F: GTCGTCTTGAGGTTTCGTTTC } \\
\text { R: AGAAGGCTAAAGCTGCACCA }\end{array}$ & $216-228$ & 6 & 0.795 & 0.815 & 0.522 & 0.780 & KJ606769 \\
\hline Ptpe_535 & $(\mathrm{TG})_{11}(\mathrm{TGTA})_{8} \mathrm{G}(\mathrm{GTAG})_{8}$ & 60 & $\begin{array}{l}\text { F: CCAGTGACTGTGGATGAATATCA } \\
\text { R: GCAAGGTTTCGGGATCATAA }\end{array}$ & $300-366$ & 17 & 0.923 & 0.945 & 0.350 & 0.929 & KJ606770 \\
\hline Ptpe_128 & $(\mathrm{TACA})_{20} \mathrm{~N}(\mathrm{ACAT})_{17}$ & 55 & $\begin{array}{l}\text { F: ATGCATGTTACTTGTATTTGTTGA } \\
\text { R: CCTCTAAATATGCCACTGGAATAG }\end{array}$ & $240-370$ & 22 & 0.308 & 0.939 & $<0.001$ & 0.923 & KJ606771 \\
\hline Ptpe_010 & $(\mathrm{TG})_{13} \mathrm{~N}(\mathrm{TGTA})_{18}$ & 60 & $\begin{array}{l}\text { F: AGTCTGGGTTTTCACTCGTAAT } \\
\text { R: CAGTTTGCCGTACAAGGTTT }\end{array}$ & $261-311$ & 26 & 0.911 & 0.944 & 0.805 & 0.929 & KJ606772 \\
\hline Ptpe_016 & $(\mathrm{CA})_{35}$ & 60 & $\begin{array}{l}\text { F: ATACCGAGTCAAGTGTCAAGTTC } \\
\text { R: TGTTCAGGTTAGCATCAATGTC }\end{array}$ & $215-281$ & 15 & 0.925 & 0.938 & 0.133 & 0.921 & KJ606773 \\
\hline Ptpe_025 & $(\mathrm{TG})_{6} \mathrm{~N}(\mathrm{TG})_{5}$ & 60 & $\begin{array}{l}\text { F: GGACTATTACAGTGTCGGTAACAA } \\
\text { R: GGACGATTTACACTCATAAGCAC }\end{array}$ & $212-234$ & 5 & 0.778 & 0.796 & 0.207 & 0.752 & KJ606774 \\
\hline Ptpe_062 & $(\mathrm{TG})_{17}$ & 60 & $\begin{array}{l}\text { F: AAACACGGGCTAAGTGAACA } \\
\text { R: ACGTAGAAGTCGATCGGTATAAG }\end{array}$ & $213-227$ & 8 & 0.854 & 0.858 & 0.529 & 0.828 & KJ606775 \\
\hline Ptpe_071 & $(\mathrm{TG})_{11} \mathrm{~N}(\mathrm{TG})_{6}$ & 66 & $\begin{array}{l}\text { F: CTGGCAGCCTGAAAGACAGT } \\
\text { R: CCAGATAACTTGAATACGATGACA }\end{array}$ & $231-261$ & 15 & 0.818 & 0.809 & 0.922 & 0.775 & KJ606776 \\
\hline Ptpe_229 & $(\mathrm{AC})_{8}$ & 58 & $\begin{array}{l}\text { F: CTGCCAAGGGAGAAGTCTGT } \\
\text { R: GCGTATTTCCTTTGCTTAGTTG }\end{array}$ & $283-297$ & 6 & 0.778 & 0.805 & 0.154 & 0.768 & KJ606777 \\
\hline
\end{tabular}

Ta: optimised annealing temperature, $N_{a}$ : Number of alleles per locus, $H_{O}$ : Observed heterozygosity, $H_{E}$ : Expected heterozygosity, $P$ : Probabilities of deviation from Hardy-Weinberg equilibrium, PIC: Polymorphism information content

polymorphism of the twelve loci with 46 individuals of the wild populations. The PCR products were detected on a 3130xl capillary DNA analyser (Applied Biosystems) using GS-500LIZ (Applied Biosystems) as the size standard. GENEPOP 4.0 software was used to calculate the observed $(\mathrm{Ho})$ and expected heterozygosities $(\mathrm{He})$, Hardy-Weinberg equilibrium and linkage disequilibrium (Rousset, 2008). Bonferroni's correction was used to correct all the results obtained in the multiple tests (Rice, 1989). Polymorphism information content (PIC) was assessed by Cervus 3.0 (Kalinowski et al. 2007).

In this study, 28 out of the 53 selected loci were successfully amplified in the wild population of P. penguin and 12 loci were found to have polymorphism (Table 1). The numbers of alleles ranged from 5 to 26 , with a mean value of 12.1. The $\mathrm{Ho}$ and $\mathrm{He}$ ranged from 0.2 to 0.925 and from 0.707 to 0.945 , with a mean value of from Hardy-Weinberg equilibrium after Bonferroni's correction $(p<0.0042)$. There was no evidence of linkage disequilibrium between any pairs of loci.

The present study developed 12 polymorphic microsatellite markers in $P$. penguin using the magnetic beads enrichment procedure. These polymorphic loci (except Ptpe_134 and Ptpe_128) can be used in study of the population structure and conservation of $P$. penguin.

\section{Acknowledgements}

This study was supported by Guangdong Province Marine Fisheries Science and Technology and Industrial Development Special Pearl Industry Development Project (Z2015012), National Infrastructure of Fishery Germplasm Resources Project and Central Institutes of Public Welfare Projects (2012TS18). 


\section{References}

Doyle, J. J. 1987. A rapid DNA isolate produce for small quantities of fresh leaf material. Phyochem. Bull., 19: 11-15.

Kalinowski, S. T., Taper, M. L. and Marshall, T. C. 2007. Revising how the computer program CERVUS accommodates genotyping error increases success in paternity assignment. Mol. Ecol., 16: 1099-1106.

Mao, Y., Liang, F. L., Yu, X. Y. and Ye, F. L. 2003. Studies on effects of nucleus implantations in Pteria penguin in different seasons. Mar. Poll. Bull., 22: 88-91.

Ma, H. Y. and Chen, S. L. 2009. Isolation and characterisation of 31 polymorphic microsatellite markers in barfin flounder (Verasper moseri) and the cross-species amplification in spotted halibut (Verasper variegatus). Conserv. Genet. 10: 1591-1595.

Peng, M., Chen, X. L., Jiang, W. M., Yang, C. L. and Li, Y. M. 2012. The population genetic diversity of different geographical Pteria penguin revealed by FAFLP analysis. Acta. Hydrobiologica Sinica, 36: 102-108.

Rice, W. R. 1989. Analysing tables of statistical tests. Evol., 43: 223-225.

Rousset, F. 2008. GENEPOP'007: a complete re-implementation of the GENEPOP software for Windows and Linux. Mol. Ecol. Resour., 8: 103-106.

Tautz, D. 1989. Hypervariability of simple sequences as a general source for polymorphic DNA markers. Nucleic Acids Res., 17: 6463-6471. 